\title{
RADIOCARBON RESERVOIR AGES AS FRESHWATER-BRINE MONITORS IN LAKE LISAN, DEAD SEA SYSTEM
}

\begin{abstract}
Mordechai Stein ${ }^{1} \cdot{\text { Boaz } \operatorname{Lazar}^{2} \bullet \text { Steven L Goldstein }}^{3}$
ABSTRACT. A continuous and high-resolution record of the radiocarbon reservoir age (RA) has been recovered from the primary aragonites that were deposited from the last glacial Lake Lisan. The RA is calculated as the difference between the measured ${ }^{14} \mathrm{C}$ "apparent" age in the aragonite and the atmospheric age at any particular time. The RA shows temporal decreases during the time interval of $\sim 28$ to $\sim 18 \mathrm{ka}$ cal BP. This behavior is attributed to a continuous addition of low RA-high bicarbonate freshwater into the high RA-Ca-chloride (low bicarbonate) brine solution filling the lake. The mixing of the brine with freshwater drives the precipitation of $\mathrm{CaCO}_{3}$ in the form of aragonite from the lake epilimnion (surface layer). The runoff-brine mixture in Lake Lisan is also reflected by the $\mathrm{Sr} / \mathrm{Ca}$ ratios that are positively correlated with the RA. Nevertheless, the ${ }^{14} \mathrm{C}$ content in the epilimnion did not drop at the same rate as the atmospheric value but rather remained nearly constant. We suggest that turbulent mixing with the much saltier hypolimnion (lower layer) across the hypolimnion/epilimnion interface at a depth of about $390 \mathrm{~m}$ below sea level, buffered the ${ }^{14} \mathrm{C}$ content as well as the $\mathrm{Sr}$ and Ca concentrations in the aragonite precipitating solution. The RA-Sr/Ca related limnological model developed here opens the way to determine the reservoirage-corrected atmospheric ages of Lisan Formation aragonites beyond 28 ka cal BP.
\end{abstract}

\section{INTRODUCTION}

Radiocarbon dating, which is based on the measurement of the ratio of ${ }^{14} \mathrm{C} /{ }^{12} \mathrm{C}$ organic and inorganic carbon-bearing material, has to take into account the variations in ${ }^{14} \mathrm{C}$ level in atmospheric carbon, which reflects changes in the cosmogenic production and/or changes in the exchange between the various carbon reservoirs. The secular variations in the atmospheric ${ }^{14} \mathrm{C}$ have been well established since $\sim 12$ ka by using tree rings. However, for older ${ }^{14} \mathrm{C}$ ages, other archives have been used: corals (e.g. Barbados, Bard et al. 1998); speleothems (e.g. Bahamas, Beck et al. 2001; Hoffman et al. 2010); foraminifera (e.g. Iceland Sea, Voelker et al. 2000); marine varves (e.g. Cariaco Basin, Hughen et al. 1998); and laminated carbonate lake sediments (e.g. lakes Suigestu and Lisan, Kitagawa and van der Plicht 2000; Schramm et al. 2000; Bronk Ramsey et al. 2012). ${ }^{14} \mathrm{C}$ dating of carbonates, however, requires an estimation of the ${ }^{14} \mathrm{C}$ "reservoir age" (RA), which accounts for contribution of old $\left({ }^{12} \mathrm{C}\right.$-enriched) carbon in the deposited material. This problem is not severe for corals, where the RA of the surrounding ocean is estimated to be around $400 \mathrm{yr}$ (cf. Bard et al. 1998; Fairbanks et al. 2005), but is often complicated in the case of speleothems and laminated lake sediments (cf. Schramm et al. 2000; Beck et al. 2001; Belmaker et al. 2007).

The efforts to define the RA for Lake Lisan trace back to the work of Schramm et al. (2000), who set up a preliminary U-Th and ${ }^{14} \mathrm{C}$ chronology for the aragonite sequences of the PZ1 (Perazim Valley) and M1 (Massada plain) sections (Figure 1). They compared ${ }^{14} \mathrm{C}$ ages of organic debris and its host aragonite laminae from the upper part of the section at the calendar time interval (determined by U-Th) of $\sim 20$ to $~ 17 \mathrm{ka}$ cal BP and obtained low RA values of almost zero to 1000 yr. Subsequently, Stein et al. (2004) used pairs of aragonite and organic debris collected from the same stratigraphic horizons in the sedimentary sections of the Holocene Dead Sea and obtained significantly older reservoir ages ranging from $\sim 6$ to $2.2 \mathrm{ka}$. They proposed that the high RA values ( 6 ka) are related to enhanced contributions from the Ca-chloride brine of the hypolimnion (the deep-water

\footnotetext{
${ }^{1}$ Geological Survey of Israel, 30 Malkhe Israel St, 95501, Jerusalem, Israel. Corresponding author. Email: motis@vms.huji.ac.il.

${ }^{2}$ Institute of Earth Sciences, The Hebrew University, Jerusalem, Israel.

${ }^{3}$ Lamont-Doherty Earth Observatory and Department of Earth and Environmental Sciences, Columbia University, Palisades, New York, USA.
}

(C) 2013 by the Arizona Board of Regents on behalf of the University of Arizona Proceedings of the 21st International Radiocarbon Conference edited by A J T Jull \& C Hatté RADIOCARBON, Vol 55, Nr 2-3, 2013, p 1050-1057 


\section{Stein et al.}

brine layer), via discharge of saline springs after a significant lake level drop (e.g. at $\sim 8.1 \mathrm{ka}$ cal BP), while low RA values ( 2 ka) reflect enhanced runoff, which was equilibrated with atmospheric ${ }^{14} \mathrm{C}$, into the epilimnion (the surface layer). Prasad et al. (2009) compared the ${ }^{14} \mathrm{C}$ ages of aragonites from the M1 Massada section (Figure 1) to the IntCal09 (Reimer et al. 2009) values and showed that reservoir ages in the lake declines systematically by $2000 \mathrm{yr}$ during the time interval 21-17.4 ka cal BP.

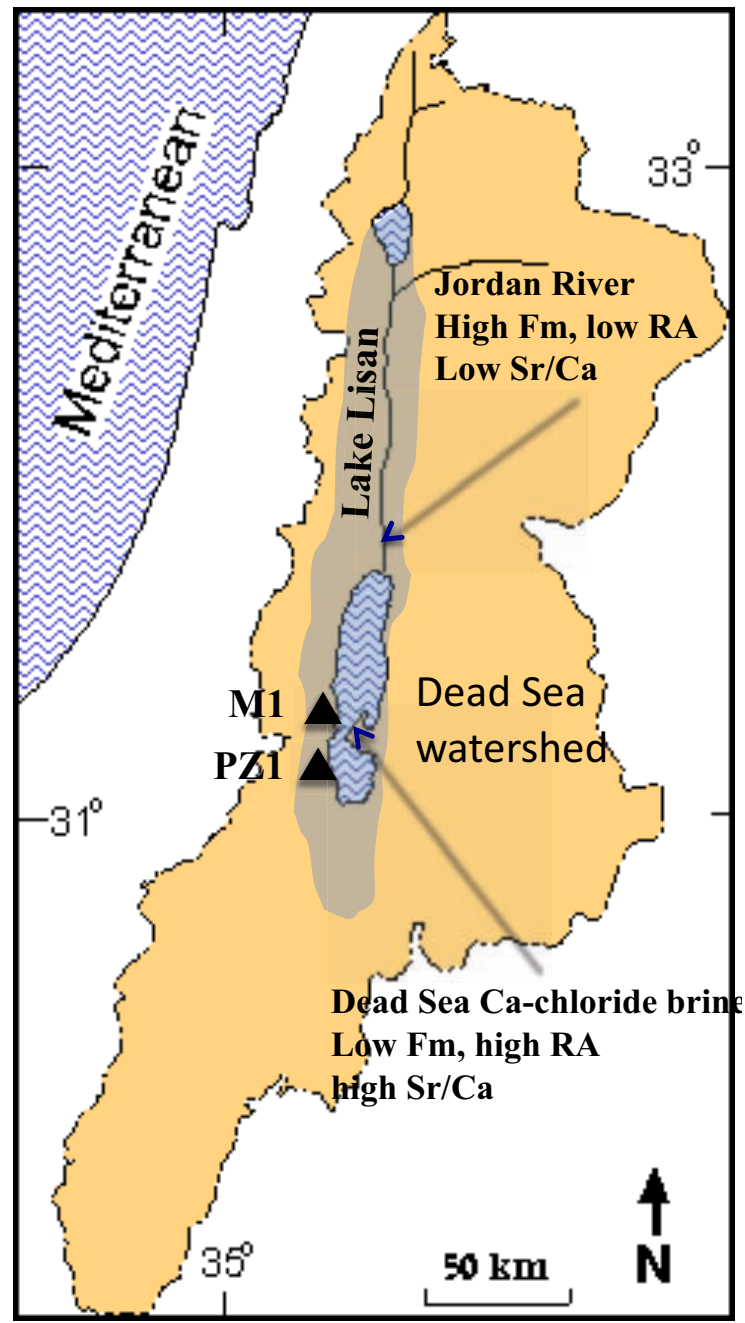

Figure 1 The Dead Sea watershed showing the northern freshwater Sea of Galilee (Lake Kinneret) the hypersaline southern Dead Sea (filled with Ca-chloride solution), and the location of the PZ1 stratigraphic section at the Perazim Valley.

Here, we follow the approach of Prasad et al. (2009) and calculate the RA values in Lake Lisan and the Holocene Dead Sea by comparing the primary aragonite ${ }^{14} \mathrm{C}$ ages with the IntCal09 calibration curve over the time interval 28-18 ka cal BP. The RA values show temporal decreases during this time interval. We interpret the decrease as reflecting the mixing between the incoming freshwater and brines in the lake, which dictate the precipitation of the primary aragonite. 
${ }^{14} \mathrm{C}$ Reservoir Ages as Freshwater-Brine Monitors in Lake Lisan

\section{SAMPLES AND METHODS}

Samples were collected from the exposed stratigraphic sections of the last glacial Lisan Formation at the Perazim Valley (PZ1 section, SW of Mt. Sedom, Figure 1). Detailed lithological descriptions of the Lisan PZ1 section are given in Machlus et al. (2000) and Haase-Schramm et al. (2004). The chronology of the PZ1 section was established by U-Th dating of the primary aragonite (HaaseSchramm et al. 2004; Torfstein et al. 2013). Aragonite samples for ${ }^{14} \mathrm{C}$ analyses were obtained from individual sediment samples taken from the exposures or from the cores.

The aragonite samples were treated with acid in an evacuated glass line in order to release and collect the $\mathrm{CO}_{2}$. In a separate step, the $\mathrm{CO}_{2}$ was converted into graphite, in which form it was used for analysis. Accelerator mass spectrometry (AMS) analyses were carried in the ${ }^{14} \mathrm{C}$ laboratory of University of Utrecht (van der Borg et al. 2004). In the AMS analyses, the yields of the carbon isotopes were measured and converted to ${ }^{14} \mathrm{C} /{ }^{12} \mathrm{C}$ ratios, which were used to calculate conventional ${ }^{14} \mathrm{C}$ ages.

\section{RADIOCARBON IN THE DEAD SEA HYDROLOGICAL SYSTEM}

Lake Lisan, which occupied the Dead Sea basin (Figure 1) during the last glacial period (70-14 ka cal BP, Haase-Schramm et al. 2004; Torfstein et al. 2013), deposited sequences of laminated primary aragonite and silty detritus, gypsum, and clastics (Machlus et al. 2000; Haliva-Cohen et al. 2012). The deposition of the primary aragonite reflects the supply of $\mathrm{Ca}$ and bicarbonate to the lake by freshwater, and some Ca and Mg from the underlying Dead Sea brine (Katz et al. 1977; Stein et al. 1997). The continuous and the annual mode of deposition of primary aragonite from the epilimnion, and the possibility to obtain U-Th ages on the aragonites, make the Lisan aragonite a potential highresolution archive for atmospheric ${ }^{14} \mathrm{C}$ calibration (Schramm et al. 2000; Haase-Schramm et al. 2004; Torfstein et al. 2013). Yet, the ${ }^{14} \mathrm{C}$ of the dissolved inorganic carbon content of the lake solution, from which the primary aragonite precipitates, is a mixture of 3 reservoirs: dissolved atmospheric $\mathrm{CO}_{2}$ supplied mainly through runoff entering the lake (Belmaker et al. 2007); “dead carbon” $\left({ }^{14} \mathrm{C}\right.$-depleted) dissolved from the surrounding Phanerozoic carbonate terrains (e.g. the Cretaceous Judean Mountain wall-rocks of the Dead Sea basin); and ${ }^{14} \mathrm{C}$ provided by saline springs that underwent water-rock interaction and ${ }^{14} \mathrm{C}$ "aging" within the aquifers (e.g. Belmaker et al. 2007). Thus, the fresh and saline solutions that enter the lake are characterized by different amounts of ${ }^{14} \mathrm{C}$ reflecting their primary source, dissolution processes, and exchange processes with the atmosphere. While the runoff water in the Judean Desert can reach atmospheric values (e.g. 0.9-1.0 Fm), the Jordan River water entering the Sea of Galilee has $\sim 0.85 \mathrm{Fm}$ and the saline springs comprising the Dead Sea Ca-chloride brine are characterized by low to very low Fm values (e.g. $\sim 0.05$ Fm, Belmaker et al. 2007).

\section{TEMPORAL CHANGES IN THE RESERVOIR AGE IN LAKE LISAN}

The ${ }^{14} \mathrm{C}$ content in the primary (chemical) aragonites deposited from Lake Lisan is compared in Figure 2 with corals and Cariaco Basin sediments that were used to construct calibration curve beyond the dendrochronology range. Here, we discuss the time interval between 18 and $28 \mathrm{ka}$ BP, which is included in IntCal09. The ${ }^{14} \mathrm{C}$ in the Lisan aragonites differs from the corals and the Cariaco data, but the difference in the apparent ${ }^{14} \mathrm{C}$ ages declines regularly from $\sim 3 \mathrm{kyr}$ at $28 \mathrm{ka}$ cal $\mathrm{BP}$ to $\sim 1 \mathrm{kyr}$ at $18 \mathrm{ka}$ cal BP. The older ${ }^{14} \mathrm{C}$ ages at each point in time in the Lisan aragonites, compared to the corals and Cariaco data. stems from higher reservoir age (RA) in the Lisan aragonites. Accordingly, the temporal decline in the difference between the Lisan aragonite and the coral-Cariaco data reflects a continuous decrease in the RA. The temporal decrease in RA reflects a change in the hydrologicallimnological conditions of the lake and a change in the reservoirs contributing ${ }^{14} \mathrm{C}$ to the lake layer 


\section{Stein et al.}

that precipitated the aragonite. We construct a hydrological-limnological model that describes a continuous replenishment of the lake water, which is initially composed of the Dead Sea Ca-chlorine brine with incoming fresh runoff waters. The Lisan aragonite is deposited from the epilimnion, comprised of a mixture of the Ca-chlorine brine and freshwater loaded with bicarbonate (Stein et al. 1997). Low RA values are attributed to freshwater runoff that rapidly exchanges ${ }^{14} \mathrm{C}$ with the atmosphere (Belmaker et al. 2007). High RA values are attributed to the brines that are discharged to the lake from the Judean Mountain aquifers. The RA declines as long as freshwaters loaded with bicarbonate enter the lake and aragonite is being deposited. The RA rises when the supply of runoff declines and mainly the Ca-chloride brines (either from the hypolimnion or saline springs) feed the epilimnion. The RA rises appear to occur during or after major declines in lake levels. Thus, the RA reflects the hydrological-limnological configuration of the lake, which is modulated by the climate regime in the drainage area, declining during wet phases and increasing during arid phases.

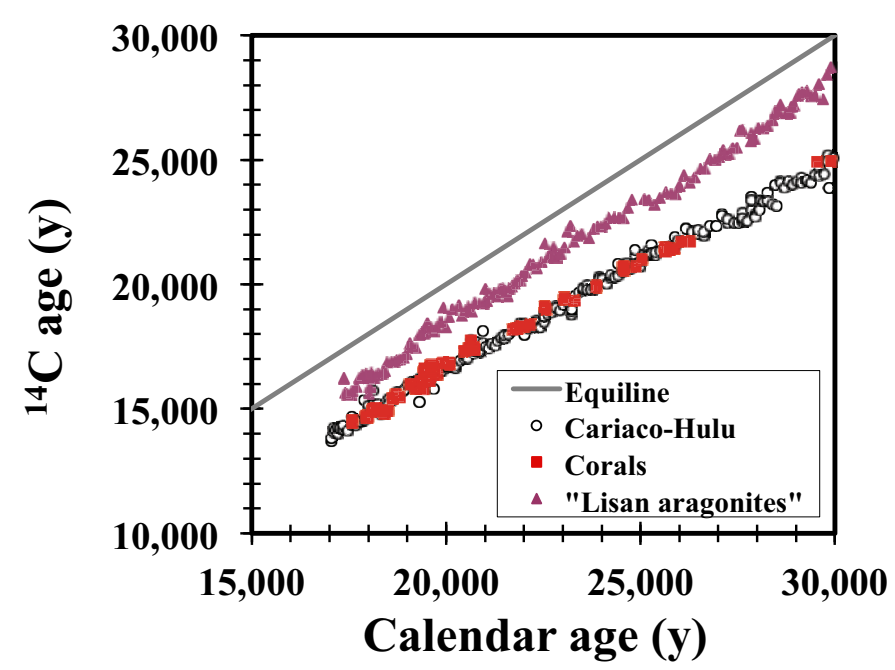

Figure $2{ }^{14} \mathrm{C}$ ages of Lake Lisan aragonites compared to Cariaco Basin sediments (ages tuned to Hulu Cave speleothems), corals, and Bahamas speleothem (data: Hughen et al. 1998; Schramm et al. 2000; van der Borg et al. 2004; Fairbanks et al. 2005).

\section{Coeval Changes in the Sr/Ca Ratio and RA in the Lake}

The precipitation of primary aragonite from Lake Lisan requires the input of freshwater containing significant bicarbonate to the lake and its mixing with the Ca-chloride brine (Stein et al. 1997). The $\mathrm{Sr} / \mathrm{Ca}$ ratio in the aragonite is a sensitive tracer of the brine-freshwater mixing, because the distribution coefficient for aragonite/water is about unity, and the $\mathrm{Sr} / \mathrm{Ca}$ ratio is high in the Ca-chloride brine and low in the freshwater runoff (Katz et al. 1977). The continuous supply of freshwater by runoff to Lake Lisan, mainly via the paleo-Jordan River, and the mixing of these waters with the brine, are reflected in the temporal decrease of the $\mathrm{Sr} / \mathrm{Ca}$ ratio in the precipitating aragonite (Katz et al. 1977; Stein et al. 1997). The Sr/Ca ratio displays an almost monotonous decline through the time interval $\sim 28-18$ ka cal BP (Figure 3), when the lake was at its highest stand. Yet, Machlus (1997) noted that the rate of decline in the Sr/Ca ratio in the Upper Member of the Lisan Formation would be much greater if the $\mathrm{Sr}$ and $\mathrm{Ca}$ were controlled just by runoff, and suggested that the ratio is buffered by supply of the Ca-chloride brine via the saline springs to the lake. Stein et al. (1997) argued that replenishment of the lower layer by the hypersaline Ca-chloride brine is required to maintain the 
meromictic (layered) lake configuration. At the highest stand of lake level, the deep brine layer was replenished by sinking of epilimnion brine, after being evaporated to high density at the shallow margins of the lake (Stein et al. 1997).

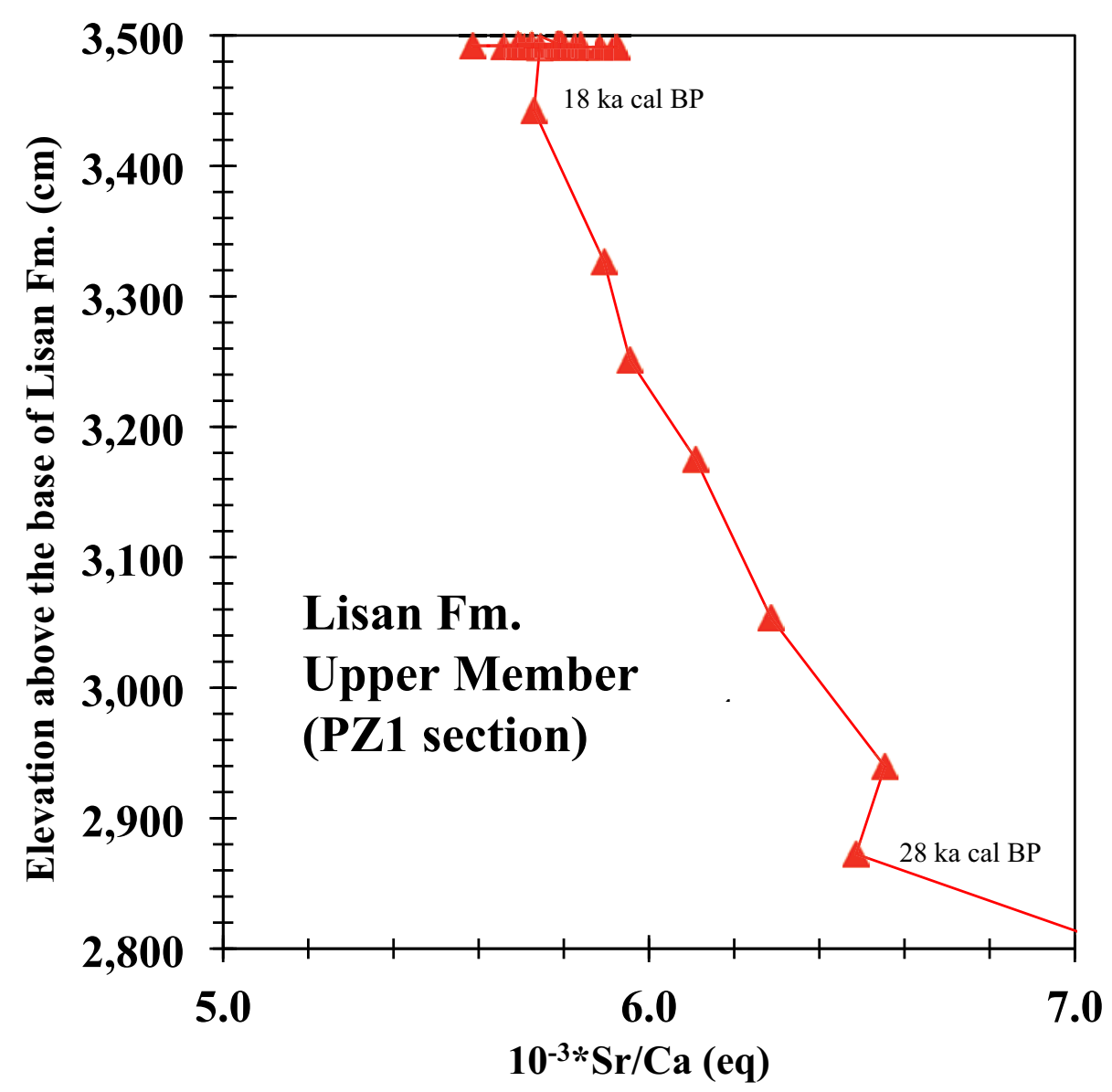

Figure $3 \mathrm{Sr} / \mathrm{Ca}$ vs. height in the Upper Member of the Lisan Formation at the PZ1 section. The continuous decline in the $\mathrm{Sr} / \mathrm{Ca}$ ratio reflects continuous input of low $\mathrm{Sr} / \mathrm{Ca}$ freshwater loaded with bicarbonate that replenish the lake and led the precipitation of the primary aragonite.

The ${ }^{14} \mathrm{C}$ content of the lake's epilimnion at time of aragonite deposition, ${ }^{14} \mathrm{C}_{0}$, is calculated from the $\mathrm{RA}$ and the atmospheric ${ }^{14} \mathrm{C}$ (IntCal09) by the equation:

$$
\ln \left({ }^{14} \mathrm{C}_{0}\right)=\ln \left({ }^{14} \mathrm{C}_{\text {IntCal09 }}\right)-\lambda_{14} \times \mathrm{RA}
$$

The aragonite laminae and the lake epilimnion represented by open circles in Figure 4 show that during the deposition of the Upper Member the lake's ${ }^{14} \mathrm{C}$ content remained almost uniform. Thus, it appears that the RA decrease during most of this time interval does not reflect the temporal drop in the atmospheric ${ }^{14} \mathrm{C}$ content. Apparently, there was a buffering mechanism that balanced the anticipated ${ }^{14} \mathrm{C}$ drop in the lake due to atmospheric exchange. The buffering of the ${ }^{14} \mathrm{C}$ content in the epilimnion is probably furnished by turbulent mixing with the hypolimnion brine. This mixing is reflected also by the contemporaneous decrease in the $\mathrm{Sr} / \mathrm{Ca}$ ratio in the aragonites (Figure 4). The 


\section{Stein et al.}

steep drop in the Sr/Ca ratio toward the end of this period, at $21 \mathrm{ka} \mathrm{BP}$, likely resulted from relatively weaker vertical mixing with the hypolimnion, causing the lake's epilimnion ${ }^{14} \mathrm{C}$ to approach the atmospheric ${ }^{14} \mathrm{C}$ value. This possibly reflects the increase in the density gradient across the epilimnion/hypolimnion interface when the supply of freshwater input increased towards the end of the high-stand Upper Member period. A more elaborate discussion of the limnological-geochemical history of Lake Lisan during its high and low stands conditions is beyond the scope of this paper, however, and will be discussed in a future publication.

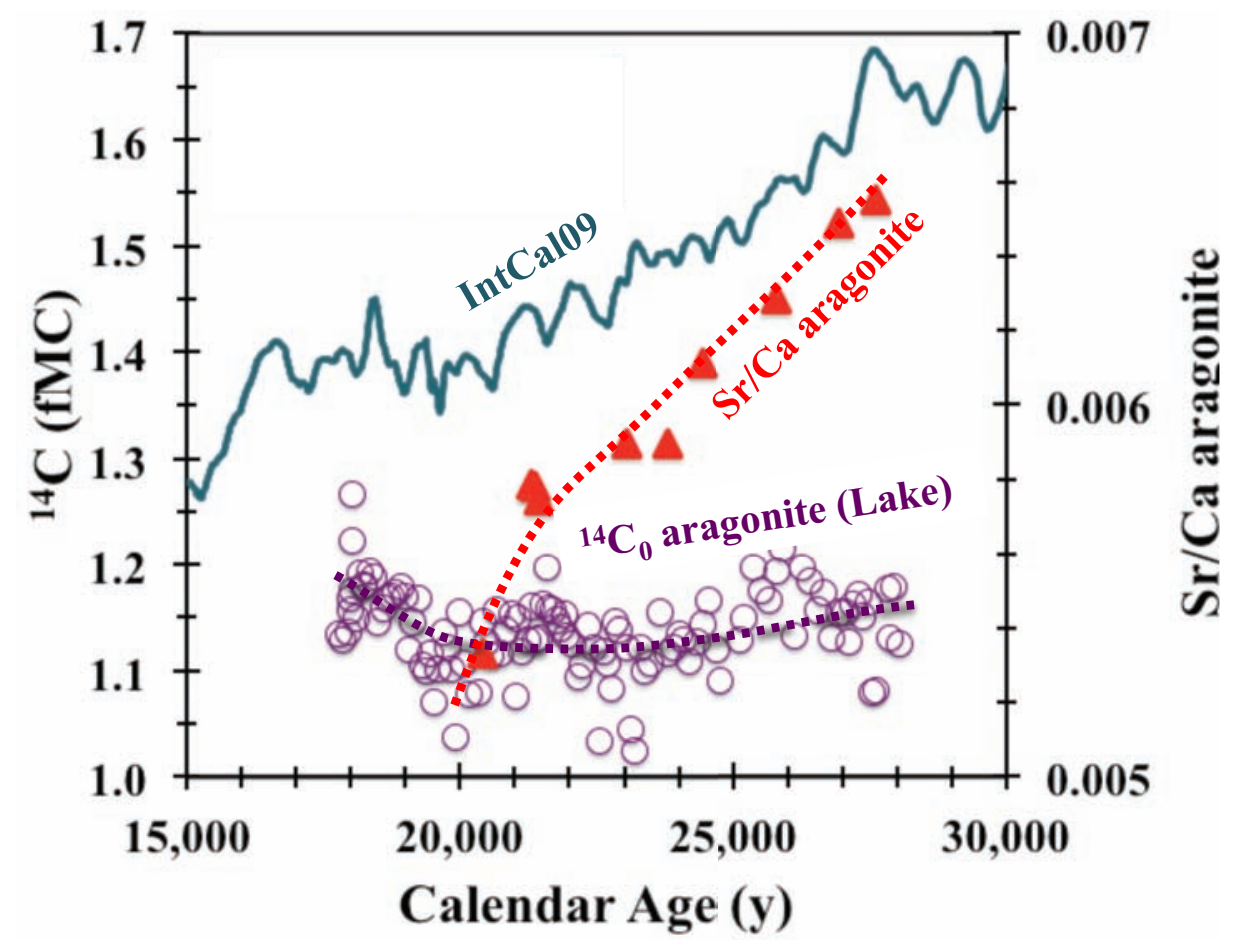

\footnotetext{
Figure 4 The calculated ${ }^{14} \mathrm{C}_{0}$ (the calculated ${ }^{14} \mathrm{C}$ value at the ${ }^{14} \mathrm{C}$ age in units of fraction modern carbon, Fm) and $\mathrm{Sr} / \mathrm{Ca}$ ratio of aragonite laminae from the upper member of Lisan Formation versus the U/Th calendar age. The ${ }^{14} \mathrm{C}_{0}$ and the $\mathrm{Sr} / \mathrm{Ca}$ ratio are assumed to be the $\mathrm{Fm}$ value and the $\mathrm{Sr} / \mathrm{Ca}$ ratio of the lake's epilimnion at the time of deposition. The ${ }^{14} \mathrm{C}$ of the atmosphere at that time is taken as the IntCal09 Northern Hemisphere atmospheric ${ }^{14} \mathrm{C}$ calibration curve (http://www.radiocarbon.org/IntCal09\%20files/intcal09.14c) recalculated in Fm units. Note that after $21 \mathrm{kyr} \mathrm{BP}$, the $\mathrm{Sr} / \mathrm{Ca}$ ratio dropped steeper than before and the ${ }^{14} \mathrm{C}_{0}$ starts to increase towards the contemporaneous atmospheric value.
}

The RA-Sr/Ca related limnological model developed here opens the way to determine the reservoirage-corrected atmospheric ages of Lisan Formation aragonites beyond $28 \mathrm{ka}$ cal BP. Combined with the U-Th chronology, and the possibility to count the annually deposited laminae, we expect that the Lisan Formation will be established as a high-resolution archive of atmospheric ${ }^{14} \mathrm{C}$ variations during the last glacial period.

\section{SUMMARY}

${ }^{14} \mathrm{C}$ ages were obtained from primary aragonites that were deposited in the last glacial Lake Lisan between 28 to $18 \mathrm{ka}$ cal BP, during Marine Isotope Stage 2, when the lake level averaged $200 \mathrm{~m}$ 


\section{${ }^{14} \mathrm{C}$ Reservoir Ages as Freshwater-Brine Monitors in Lake Lisan}

higher than typical Holocene levels. The ages display a declining deviation from the IntCal09 calibration curve through time, which reflects a temporal decrease in the lake reservoir age (RA). The decrease in RA is accompanied by a decrease in the $\mathrm{Sr} / \mathrm{Ca}$ ratios in the aragonite laminae reflecting the decreasing $\mathrm{Sr} / \mathrm{Ca}$ ratio in the surface layer of the lake (the epilimnion).

The chemical composition of the epilimnion was dictated by freshwater input that continuously replenished the lake with high bicarbonate, low $\mathrm{Sr} / \mathrm{Ca}$ and high Fm runoff, and by Ca-chloride brine, with low bicarbonate, high $\mathrm{Sr} / \mathrm{Ca}$, and low $\mathrm{Fm}$. We suggest that turbulent mixing across the hypolimnion/epilimnion interface buffered the ${ }^{14} \mathrm{C}$, $\mathrm{Sr}$, and $\mathrm{Ca}$ contents in the epilimnion, slowing the rate of decrease in the $\mathrm{Sr} / \mathrm{Ca}$ ratio in the aragonite precipitating solution and causing the ${ }^{14} \mathrm{C}$ content to remain nearly constant.

\section{ACKNOWLEDGMENTS}

This paper benefited from fruitful conversations with Klaas van der Borg, Reuven Belmaker, Amitai Katz, and Abraham Starinsky. The study was supported by the US-Israel Bi-National Science Foundation (BSF) Grant \#2010.375 to MS and SG and by Israel Science Foundation (ISF) Center of Research Grant \#1736/11 to BL.

\section{REFERENCES}

Bard E, Arnold M, Hamlin B, Tisnerat-Laborde N, Cabioch G. 1998. Radiocarbon calibration by means of mass spectrometric ${ }^{230} \mathrm{Th} /{ }^{234} \mathrm{U}$ and ${ }^{14} \mathrm{C}$ ages of corals: an updated database including samples from Barbados, Mururoa and Tahiti. Radiocarbon 40(3):198592.

Beck JW, Richards DA, Edwards RL, Silverman BW, Smart PL, Donahue DJ, Hererra-Osterheld S, Burr GS, Calsoyas L, Jull AJT, Biddulph D. 2001. Extremely large variations of atmospheric ${ }^{14} \mathrm{C}$ concentration during the last glacial period. Science 292(5526): 2453-8.

Belmaker R, Stein M, Yechieli Y, Lazar B. 2007. Controls on the radiocarbon reservoir ages in the modern Dead Sea drainage system and in the last glacial Lake Lisan. Radiocarbon 49(2):969-82.

Bronk Ramsey C, Staff RA, Bryant CL, Brock F, Kitagawa $\mathrm{H}$, van der Plicht J Schlolaut G, Marshall $\mathrm{MH}$, Brauer A, Lamb HF, Payne RL, Tarasov PE, Haraguchi T, Gotanda K, Yonenobu H, Yokoyama Y, Tada R, Nakagawa T. 2012. A complete terrestrial radiocarbon record for 11.2 to $52.8 \mathrm{kyr}$ B.P. Science 338(6105): 370-4.

Fairbanks RG, Mortlock RA, Chiu TC, Cao L, Kaplan A, Guilderson TP, Fairbanks TW, Bloom AL, Grootes PM, Nadeau MJ. 2005. Radiocarbon calibration curve spanning 0 to 50,000 years BP based on paired ${ }^{230} \mathrm{Th} /$ ${ }^{234} \mathrm{U} /{ }^{238} \mathrm{U}$ and ${ }^{14} \mathrm{C}$ dates on pristine corals. Quaternary Science Reviews 24:1781-96.

Haase-Schramm A, Goldstein SL, Stein M. 2004. U-Th dating of Lake Lisan (late Pleistocene Dead Sea) aragonite and implications for glacial east Mediterranean climate change. Geochimica et Cosmochimica Acta 68:985-1005.
Haliva-Cohen A, Stein M, Goldstein SL, Sandler A, Starinsky A. 2012. Sources and transport routes of fine detritus material to the late Quaternary Dead Sea basin. Quaternary Science Reviews 49:55-70.

Hoffman DL, Beck JW, Richards DA, Smart PL, Singarayer JS, Ketchmark T, Hawkesworth CJ. 2010. Towards radiocarbon calibration beyond $28 \mathrm{ka}$ using speleothems from the Bahamas. Earth Planetary Science Letters 289:1-10.

Hughen KA, Jonathan T, Overpeck JT, Lehman SJ, Kashgarian M, Southon J, Petersonk LC, Alley R, Sigman DM. 1998. Deglacial changes in ocean circulation from an extended radiocarbon calibration. Nature 391(6662):65-8.

Katz A, Kolodny Y, Nissenbaum A. 1977. The geochemical evolution of the Pleistocene Lake Lisan-Dead Sea system. Geochimica et Cosmochimica Acta 41:160926.

Kitagawa H, van der Plicht J. 1998. Atmospheric radiocarbon calibration to 45,000 yr B.P. Late Glacial fluctuations and cosmogenic isotope production. Science 279(5354):1187-90.

Machlus M. 1997. Geochemical parameters in the Lisan Formation aragonite-proxies for paleolimnology of Lake Lisan and the climatic history of the Dead Sea region [MSc thesis]. Hebrew University of Jerusalem.

Machlus M, Enzel Y, Goldstein SL, Marco S, Stein M. 2000. Reconstruction of low-levels of Lake Lisan between 55 and 35 kyr. Quaternary International 73-74: 137-44.

Prasad S, Negendank J, Stein M. 2009. High-resolution radiocarbon reservoir age variations in palaeolake Lisan by varve counting. Journal of Quaternary Science 24:690-6. 


\section{Stein et al.}

Reimer PJ, Baillie MGL, Bard E, Bayliss A, Beck JW, Blackwell PG, Bronk Ramsey C, Buck CE, Burr GS, Edwards RL, Friedrich M, Grootes PM, Guilderson TP, Hajdas I, Heaton T, Hogg AG, Hughen KA, Kaiser KF, Kromer B, McCormac FG, Manning SW, Reimer RW, Richards DA, Southon JR, Talamo S, Turney CSM, van der Plicht J, Weyhenmeyer CE. 2009. IntCal09 and Marine09 radiocarbon age calibration curves, $0-50,000$ years cal BP. Radiocarbon 51(4): 1111-50.

Schramm A, Stein M, Goldstein SL. 2000. Calibration of the ${ }^{14} \mathrm{C}$ timescale to $50 \mathrm{kyr}$ by ${ }^{234} \mathrm{U}-{ }^{230} \mathrm{Th}$ dating of sediments from Lake Lisan (the paleo-Dead Sea). Earth Planetary Science Letters 175:27-40.

Stein M, Starinsky A, Katz A, Goldstein SL, Machlus M, Schramm A. 1997. Strontium isotopic, chemical, and sedimentological evidence for the evolution of Lake Lisan and the Dead Sea. Geochimica et Cosmochim- ica Acta 61:3975-92.

Stein M, Migowski C, Bookman R, Lazar B. 2004. Temporal changes in the radiocarbon reservoir age in the Dead Sea. Radiocarbon 46(2):649-55.

Torfstein A, Goldstein SL, Kagan E, Stein M. 2013. Integrated multi-site U-Th chronology of the last glacial Lake Lisan. Geochimica et Cosmochimica Acta 104: 210-31.

van der Borg K, Stein M, de Jong AFM, Waldmann N, Goldstein SL. 2004. Near-zero $\Delta^{14} \mathrm{C}$ values at $32 \mathrm{kyr}$ cal BP observed in the high-resolution ${ }^{14} \mathrm{C}$ record from U-Th dated sediment of Lake Lisan. Radiocarbon 46(2):785-95.

Voelker AHL, Grootes PM, Nadeau MJ, Sarnthein M. 2000. Radiocarbon levels in the Iceland Sea from 25 $53 \mathrm{kyr}$ and their link to the Earth's magnetic field intensity. Radiocarbon 42(3):437-52. 